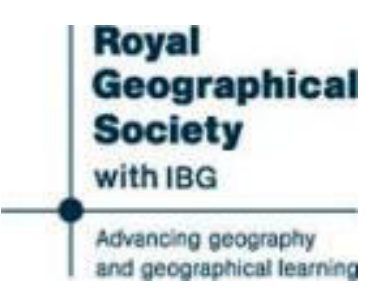

The Recent Territorial Arrangements in Africa

Author(s): E. G. Ravenstein

Source: The Geographical Journal, Vol. 4, No. 1 (Jul., 1894), pp. 54-58

Published by: The Royal Geographical Society (with the Institute of British Geographers)

Stable URL: http://www.jstor.org/stable/1774176

Accessed: 27-02-2015 06:11 UTC

Your use of the JSTOR archive indicates your acceptance of the Terms \& Conditions of Use, available at http://www.jstor.org/page/info/about/policies/terms.jsp

JSTOR is a not-for-profit service that helps scholars, researchers, and students discover, use, and build upon a wide range of content in a trusted digital archive. We use information technology and tools to increase productivity and facilitate new forms of scholarship. For more information about JSTOR, please contact support@jstor.org.

The Royal Geographical Society (with the Institute of British Geographers) is collaborating with JSTOR to digitize, preserve and extend access to The Geographical Journal. 
which lies between the Kuen-Lun range and the route taken by Captain Bower, is shown as a blank. Russian maps show ranges of hills on this tract which may possibly exist, but are as yet purely conjectural. Thus a blank, with the word "unexplored" printed across it, has been adopted as at present preferable.

As regards the values of the co-ordinates which have been adopted for the construction of this map, to the south and west they have all been derived from the Indian Survey. Elsewhere several latitudes have been determined astronomically by various explorers, which are sufficiently accurate for the purposes of a map on a small scale. The longitudes are less reliable, having, without exception, been deduced from the traverses of the routes.

The longitude of Sachu or Saitu in Mongolia may be taken as an obligatory point. The value adopted for this map is $94^{\circ} 54^{\prime}$ east of Greenwich, which is the revised value given by Prjevalski in the map accompanying the account of his fourth exploration into Central Asia. Other values are as follows:-

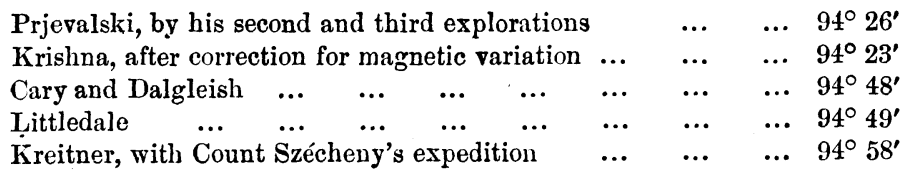

The longitude of Darchendo or Ta Chien Lu, on the extreme east, may be taken as another obligatory point. The adopted value is $102^{\circ} 12^{\prime}$

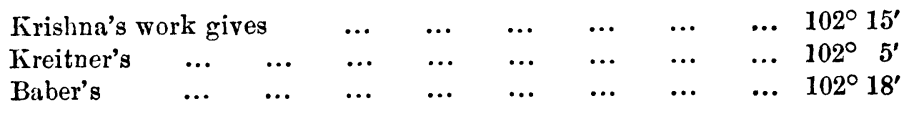

\section{THE RECENT TERRITORIAL ARRANGEMENTS IN AFRICA.}

By E. G. RAVENSTEIN.

We present the readers of the Journal with two sketch-maps designed to illustrate the territorial changes in Africa which have been brought about by the agreements concluded on May 3 at Rome and on May 12 at Brussels. The agreement with King Leopold, as sovereign of the "Independent Congo State," is interesting on account of the novel political "leaseholds" which it creates. It deals with territories covering 209,350 square miles, of which 175,530 square miles are leased to King Leopold, whilst 16,910 are assigned to Great Britain.

In the extreme south the Congo State definitely withdraws its pretensions to 14,000 square miles of territory lying between Lake Bangweolo and the Luapula. The line separating British Central Africa from the Congo State is to be drawn from Cape Akalunga 


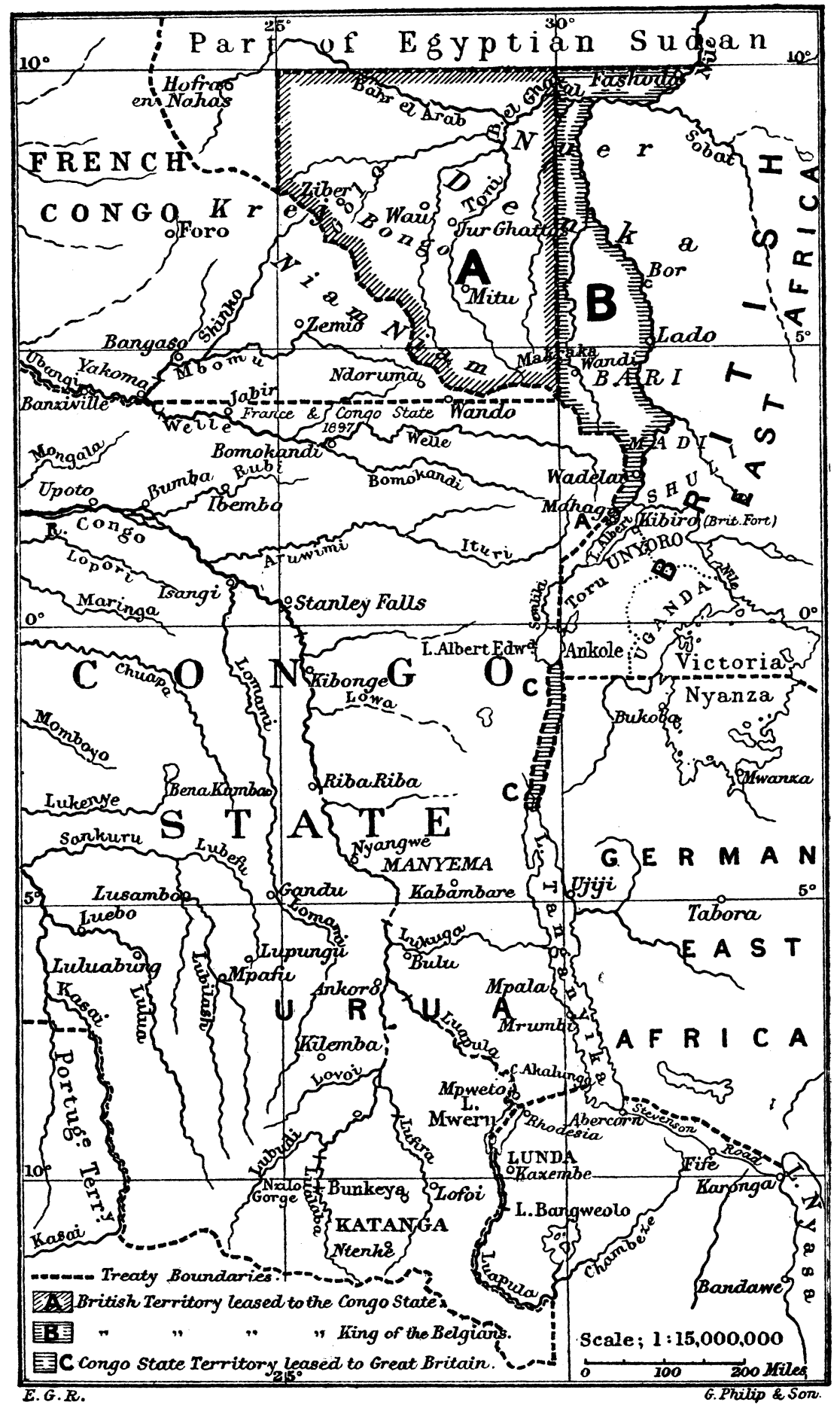

MAP TO ILLCSTRATE THE ANGLO-CONGO ARRANGEMENT. 
$\left(\tilde{5}^{\circ} 15^{\prime} \mathrm{S}\right.$.) on the Tanganyika to the debouchure of the Luapula from Lake Mweru.

The king has, moreover, granted to Great Britain a lease of a strip of territory $15 \frac{1}{2}$ miles broad, 188 miles in length, and consequently 2910 miles in area, which, lying along the north-western boundary of German East Africa, connects Lake Tanganyika with Lake Albert Edward. This lease is to remain in force so long as the territories now constituting the Congo State shall remain under the sovereignty of King Leopold and his successors. This territory is to be administered by Great Britain, who will thus be able to build a railway across it. In addition to this, the Congo State authorizes the construction through its territory by Great Britain, or by any company duly authorized by the British Government, of a line of telegraph connecting British Central Africa with the British sphere of influence on the Nile. It is probable, however, that the arrangement with regard to this strip will be modified.

Far more extensive have been the territorial changes in the Nile region. Art. 1 of the agreement defines the boundary separating the Congo State from the British sphere as following the 30th meridian as far north as the watershed between the Nile and the Congo, and thence following that watershed. This implies the definite surrender to the Congo State and its eventual successor of a territory of 9950 square miles, watered by the head-streams of the Welle-Ubangi and Aruwimi, both of which are tributary to the Congo.

The territory marked $\mathbf{B}$ upon our map is granted on lease to King: Leopold II., who will administer it. This lease will lapse as soon as the king shall cease to be sovereign of the Congo State; but a strip of territory 15 miles in width, connecting I ake Albert at Mahagi with the Congo basin, shall then revert to the Congo State. This territory is bounded on the east by the Nile, on the west by the watershed of the Nile and the 30th meridian, and on the north by the 10th parallel. Its area is 42,790 square miles. Within it lie the well-known places of Wadelai, Dufile, Kirri (where the Nile becomes navigable), Lado, and Fashoda. The existing tribal boundaries have been ignored in this, as in most preceding African agreements.

Finally, the territory marked $\mathbf{A}$, and bounded by the 25th and 30 th meridians, the watershed of the Nile, and the 10th parallel, has been leased to the Congo State, the lease to remain in force so long as the Congo territories, as an independent state or Belgian colony, shall remain under the sovereignty of King Leopold or his successors.

British Somaliland, as defined in conventions concluded with France (February 1, 1888) and Italy (May 5, 1894), includes an area of 75,200 square miles. This "protectorate" dates from 1884, in which year Great Britain occupied Berbera, Bulhar, and Zaila (Zeyla). In $188 \tilde{5}$ treaties were made with the Isa, Gadabirsi, and Habr Awal; and by 


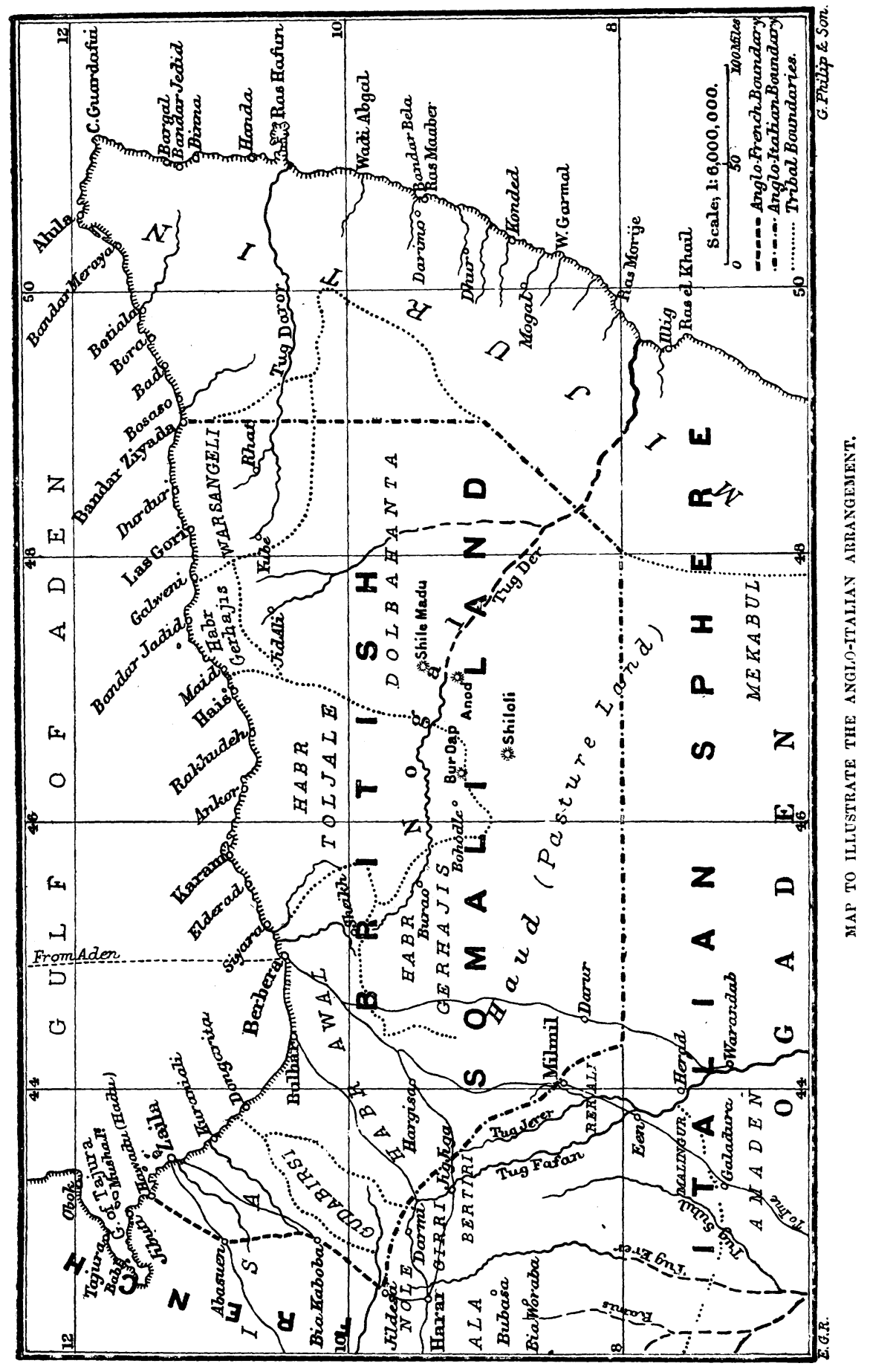


an Order in Council, dated December 19, 1889, a protectorate was proclaimed over the whole coast, extending from Ras Jibuti, at the mouth of the Gulf of Tajura, to Bandar Ziyada. In 1887 Great Britain recognized the French protectorate over Obok and Tajura, to the west of Ras Jibuti, and ceded the Musha Islands. According to an agreement concluded in 1888, the boundary separating the British and French protectorates begins at the wells of Hadu, on the coast between Jibuti and Zaila, and runs by way of Abasuen, Bia Kaboba, and Jildesa, in the direction of Harar. That important commercial town, since 1887 occupied by Menelik, the Emperor of Ethiopia, was not to be annexed by either France or Great Britain, both retaining the right of opposing attempts on the part of any other power to acquire or assert any right over the town. Great Britain has now waived this right in favour of Italy, for the boundary agreed upon commences at Jildesa, passes to the north or east of Darmi Jig-jiga and Milmil, then follows the 8 th parallel to $48^{\circ} \mathrm{E}$., and ultimately reaches the coast in $49^{\circ} \mathrm{E}$., near Bandar Ziyada. The territories of the Girri, Bertiri, and Rer Ali in the west, of the Ogaden in the south, and of the Mijurtin in the east, are assigned to Italy, whilst a portion of the Isa, the Gadabirsi, the Habr Awal, the Habr Gerhajis, the Habr Toljale, the Warsangeli, and Dolbahanta live within the British protectorate. Italy claims Harar as a dependency of Abyssinia, over which she assumed a protectorate duly notified to the powers in 1889, in accordance with Art. 34 of the "Act" of Berlin. 'At the same time, it should be borne in mind the Emperor Menelik in 1891, and again in 1893, denounced that article of the treaty of September, 1889, which placed the conduct of the foreign relations of his empire in the hands of the Italian Government.

\section{THE MONTHLY :RECORD.}

\section{EUROPE.}

Vestiges of Village Communities in England.-Mr. H. T. Crofton, in a paper published in the last number of the Manchester Geographical Society's Journal, shows how the irregular boundaries of existing townships and even of counties in England were created by the demands of the pre-Roman village communities. The later manors perpetuated or only slightly altered the boundaries, which gradually acquired permanence. A superficial study of the 6-inch Ordnance Survey map discloses the fact that counties frequently have scattered portions cut off from the main mass, and this is more especially the case with townships and parishes. In a few cases this may be accounted for by the changing course of rivers. Along the course of the formerly widespread Mersey, portions of Lancashire and Cheshire are found on what may be called the wrong side of the river, simply because the river has changed its course. But the usual explanation of such features must be the habits of early peoples in their separate divisions of the family, the tribe, and the nation. The village community existed in Celtic times, before the advent of the Romans. It is known that among the lower classes it was customary for the youngest son to inherit the homestead; among the upper classes all had equal 